\title{
Синдром остеодистрофії та локальний кровобіг після хірургічного лікування виразкової хвороби шілунка
}

\author{
YU. M. FUTUYMA \\ SHEI "Ternopil State Medical University by I. Ya. Horbachevsky" \\ OSTEODYSTROPHY SYNDROME AND LOCAL BLOOD CIRCULATION AFTER SURGICAL TREATMENT OF \\ GASTRICULCER
}

\begin{abstract}
Детальний аналіз 138 денситограм паціснтів після хірургічного лікування виразкової хвороби шлунка та значень локального кровобігу слизової оболонки оперованого шлунка свідчить про кореляційний зв'язок між вказаними показниками в розвитку остеодстрофії кісткової тканини у даної категорії хворих.
\end{abstract}

The detailed analysis of 138 densytograms of patients after the surgical treatment of peptic ulcer and values of local blood circulation of operated stomach mucosa shows the correlation between these parameters in the development of osteodystrophy bone tissue in these patients.

Постановка проблеми і аналіз останніх досліджень та публікацій. Проведені експериментальні й клінічні дослідження закордонних та вітчизняних вчених вказують на те, що багато патологічних, деструктивних і дистрофічних процесів у кістках розвиваються як наслідок захворювань внутрішніх органів, передусім при захворюваннях шлунка (зокрема, після операцій), жовчних шляхів, печінки $[4,9]$. Розвиток синдрому остеодистрофії після проведених оперативних втручань на шлунку, в зв'язку з анатомічною перебудовою ШКТ, зумовлений рядом факторів, що сприяють порушенню мінерального та кісткового обміну, а саме: обмеженням у щоденному вживанні продуктів харчування, оскільки у таких хворих недотримання дієти може спровокувати діарею та демпінг-синдром, порушенням абсорбції та обміну вітаміну D, що потрапляє 3 їжею, втратою його з калом та сечею, зв'язуванням вітаміну D та його метаболітів жовчними кислотами, пошкодженням 25-гідроксилювання вітаміну D в печінці $[1,8,10,11,12]$.

Вагомі результати, отримані в процесі дослідження локального кровобігу (ЛК) в слизовій оболонці шлунка (СОШ), вказують на його зниження у хворих на виразкову хворобу шлунка (ВХШ), що відбувається на рівні мікроциркуляторного русла $[5$, 6]. Залишається зниженим ЛК і після проведеного оперативного втручання $[2,3]$.
Мета роботи: вивчити залежність змін мінеральної щільності кісткової тканини та біохімічних маркерів кісткового метаболізму від методу оперативного лікування шлункових виразок у віддаленому періоді після операції та їх зв'язок із швидкістю ЛК в початковому відділі певної анатомічної ділянки тонкого кишечника.

Матеріали і методи. Стан МЩКТ після оперативного лікування виразкової хвороби шлунка вивчали у 138 пацієнтів віком 30-72 роки у віддаленому післяопераційному періоді до 18 років методом двофотонної рентгенівської денситометрії [7]. 3 цієїгрупи ЛК вивчали у 67 осіб полярографічним методом за водневим кліренсом із застосуванням імпульсного режиму реєстраційної швидкості очищення слизової оболонки від водню під час фіброгастроскопії [6]. Щодо розподілу за статтю: чоловіків було 103 $(74,6 \%)$, жінок - 35 (25,4 \%). Середній вік всіх обстежених становив $(55,97 \pm 1,01)$ року.

За методом проведеного типу оперативного лікування пацієнтів поділено на 3 групи: до першої групи ввійшли 44 (31,9\%) хворих, яким виконано ПРІСШ за Л. Я. Ковальчуком; до другої - 49 (35,5 \%) пацієнтів після резекції за Більрот-I; до третьої - 45 (32,6 \%) осіб після резекції за Більрот-ІІ в модифікації Гофмейстера-Фінстерера. У кожній групі провели розподіл по підгрупах, які включали пацієнтів із нормальною МЩКТ, остеопенією та 
остеопорозом. Оцінку результатів за статтю не проводили, оскільки після розподілу по вікових підгрупах та по підгрупах за станом МЩКТ кількість осіб жіночої статі була низька для підрахунку достовірності результатів.

Результати досліджень та їх обговорення. Кількісний аналіз результатів, проведених за показником $\mathrm{T}$, вказує на зростання частоти розвитку остеопеній та остеопорозу у пацієнтів після резекцій за Більрот-I та Більрот-ІІ порівняно з органощадним методом ПРІСШ та, відповідно, зниження в них кількості осіб із нормальною МЩКТ (табл. 1).

Із зниженням показника T зростає ризик розвитку ускладнень, притаманних для даної патології. Проведені дослідження стану кісткового обміну після хірургічного лікування шлункових виразок показали наростання патології опорно-рухового апарату при наявності порушень мінеральної щільності кісткової тканини, а саме виникнення переломів у післяопераційному періоді, що власне і характеризують синдром остеодистрофії, із більшою частотою та складністю ï у пацієнтів, оперованих за методами Більрота. Частка переломів, що виникли на грунті остеопорозу, становить 15,21 \% від всіх оперованих хворих. Таким чином, у післяопераційному періоді в зв'язку з травмою виникали переломи у 4-х пацієнтів, оперованих методом ПРІСШ з остеопорозом, в яких максимальний Т у всій групі коливався від $-2,5$ до -3,0, а саме - п'яткової кістки, гомілки, великого пальця стопи та хребта без пошкодження спинного мозку; в групі оперованих за Більрот-І на фоні остеопорозу, де Т від -3, 0 до -4,5, спостерігався перелом Колліса у 2 -х, гомілки - у 2-х, шийки стегна - в 1-го пацієнта, крім того, в пацієнтки О. в періоді через 8-10 років після операції в дворічний термін у зв'язку з травмами було 2 переломи ребер, п'яткової кістки та Колліса зліва ( $\mathrm{T}_{\text {L1-L4 }}-$ $(-3,6))$; в оперованих другим методом Більрота, де коливання Т у 8-ми пацієнтів становило від -3,0 до $-5,7$, виявлено: перелом шийки стегна - у 3 -х, перелом Колліса - у 3-х та перелом гомілки та ребра - у 2 -х обстежених.

Не менш важливе значення має вивчення МЩКТ відносно середнього популяційного показника Age Matched, оскільки він дає власне реальну картину відхилення від норми для пацієнта того ж віку (табл. 2).

Оцінюючи результати, слід зауважити наявність достовірно $(\mathrm{P}<0,01)$ нижчого показника кісткової маси вже в осіб із нормальною МЩКТ після резекції за Більрот-ІІ порівняно з ПРІСШ, поєднаною з СПВ. Показники остеопенії та остеопорозу між різними групами мало відрізняються між собою $(\mathrm{P}>0,05)$. В кожній окремій групі відмічається значне зниження відсотка між рівнем остеопенії та нормою, а також між остеопенією та остеопорозом, особливо у хворих після резекційних методів Більрота, де $\mathrm{P}<0,001$.

Таблиця 1. Стан кісткової тканини в $L_{1}-L_{4}$ у пацієнтів після операції за показником $T$

\begin{tabular}{|c|c|c|c|c|c|c|c|}
\hline \multirow{3}{*}{$\begin{array}{c}\text { Стан кісткової } \\
\text { тканини }\end{array}$} & \multirow{3}{*}{$\begin{array}{l}\text { Стандартне } \\
\text { відхилення }\end{array}$} & \multicolumn{6}{|c|}{ Методи оперативного лікування } \\
\hline & & \multicolumn{2}{|c|}{ ПРІСШ } & \multicolumn{2}{|c|}{ Більрот-I } & \multicolumn{2}{|c|}{ Більрот-II } \\
\hline & & абс. & $\%$ & абс. & $\%$ & абс. & $\%$ \\
\hline Нормальна МЩКТ & від 1,0 до $(-1,0)$ & 28 & 63,6 & 19 & 38,8 & 10 & 22,2 \\
\hline Остеопенія І ступеня & від $(-1,1)$ до $(-1,5)$ & 3 & 6,8 & 9 & 18,4 & 2 & 4,5 \\
\hline Остеопенія II ступеня & від $(-1,6)$ до $(-2,0)$ & 5 & 11,4 & 7 & 14,3 & 4 & 8,9 \\
\hline Остеопенія III ступеня & від $(-2,1)$ до $(-2,4)$ & 3 & 6,8 & 2 & 4,0 & 6 & 13,3 \\
\hline Остеопороз & $\begin{array}{l}\text { від }(-2,5) \\
\text { і нижче }\end{array}$ & 5 & 11,4 & 12 & 24,5 & 23 & 51,1 \\
\hline Всього & & 44 & 100 & 49 & 100 & 45 & 100 \\
\hline
\end{tabular}

Таблиця 2. Мінеральна насиченість КТ в ділянці $\mathrm{L}_{1}-\mathrm{L}_{4}$ оперованих пацієнтів відносно свого віку (Age Matched \%, Z)

\begin{tabular}{|c|c|c|c|c|c|c||}
\hline \hline \multirow{2}{*}{$\begin{array}{c}\text { Стан } \\
\text { МЩКТ }\end{array}$} & \multicolumn{2}{|c|}{ ПРІШ } & \multicolumn{2}{c|}{ Більрот-I } & \multicolumn{2}{c||}{ Більрот-II } \\
\cline { 2 - 7 } & $\mathrm{AM} \%$ & $\mathrm{Z}$ & $\mathrm{AM} \%$ & $\mathrm{Z}$ & $\mathrm{AM} \%$ & $\mathrm{Z}$ \\
\hline Нормальна & $105,07 \pm 1,61$ & $0,46 \pm 0,14$ & $106,68 \pm 1,98$ & $0,57 \pm 0,17$ & $97,1 \pm 1,91^{*}$ & $-0,39 \pm 0,18^{*}$ \\
\hline Остеопенія & $89,63 \pm 2,18^{\mathrm{x}}$ & $-1,0 \pm 0,21^{\mathrm{x}}$ & $92,5 \pm 1,49^{\mathrm{x}}$ & $-0,73 \pm 0,14^{\mathrm{x}}$ & $93 \pm 2,41$ & $-0,73 \pm 0,21$ \\
\hline Остеопороз & $79,2 \pm 1,52^{+}$ & $-1,92 \pm 0,12^{+}$ & $79,58 \pm 2,57^{++}$ & $-1,85 \pm 0,24^{++}$ & $76 \pm 1,74^{++}$ & $-2,31 \pm 0,17^{++}$ \\
\hline \hline
\end{tabular}

Примітки:

1) * - достовірність показників порівняно з нормальною МЩКТ відносно 1-ї групи ( $<00,01)$;

$2)^{\mathrm{x}}$ - достовірність показників порівняно з нормою однойменної групи $(\mathrm{P}<0,001)$;

$3)^{+}$- достовірність показників порівняно з остеопенією в однойменній групі $\left(^{+}-\mathrm{P}<0,01 ;^{++}-\mathrm{P}<0,001\right)$. 
Показник $\mathrm{Z}$ в середньому перебував у межах $(-1,92 \pm 0,12)$ у 5 осіб з остеопорозом після ПРІСШ, у межах $(-1,85 \pm 0,24)$ у 12 хворих після Більрот-І та у межах $(-2,31 \pm 0,17)$ у 23 пацієнтів після Більрот-II, що свідчить про виражені остеопоротичні зміни в кістковій тканині у цих пацієнтів із низьким відсотком їх присутності після ПРІСШ та значним - після резекції за Більрот-II.

Щодо показників біохімічних маркерів кісткового обміну, а саме коливання в сироватці крові рівня $\mathrm{Ca}, \mathrm{P}$, активності лужної фосфатази, спостерігається поступове зростання рівня кальцію та неорганічного фосфору в сироватці крові пацієнтів 3 остеопенією та остеопорозом відносно нормальної МЩКТ у кожній окремій групі з достовірною різницею у 2-й групі для кальцію та фосфору і в 3-й для кальцію (табл. 3), що здійснюється за рахунок переважання процесів демінералізації кісток у цієї категорії хворих. Разом з тим, зростає активність ферменту ЛФ, що відіграє важливу роль у мінералізації кістки, а саме в процесі її ремодуляції, з достовірністю від $\mathrm{P}<0,01$ до $\mathrm{P}<0,001$ між нормальною МЩКТ і станами остеопенії та остеопорозу в осіб, оперованих за методом Більрот-I та Більрот-II.
Отже, дані результати свідчать як про підвищений процес резорбції кісткової тканини при остеопенічних станах, так і про одночасне включення захисних механізмів ремоделювання кістки, а отже, про підтримку організмом мінерального гомеостазу внутрішнього середовища шляхом його гуморальної регуляції.

Вивчаючи ЛК, відмітили цікаву закономірність, при якій у пацієнтів з остеопеніями та остеопорозом у досліджуваних ділянках відмічався нижчий кровобіг порівняно з тими, в яких змін у кістковій тканині не виявлено. У таблиці 4 представлено дані ЛК у ділянці ДПК та початкового відділу тонкої кишки у пацієнтів після вказаних методів оперативного лікування залежно від стану МЩКТ.

Досліджуючи ЛК в осіб із різним станом кісткового обміну після ПРІСШ, відмічено його зниження у пацієнтів з остеопенією на 4,1 \% та з остеопорозом на 7,4 \% порівняно з показником ЛК осіб із нормальною МЩКТ. Однак ці показники майже не відрізняються від контролю, а невелика кількість осіб із остеопорозом у даній групі не дозволяє достовірно пов' язати зміни ЛК залежно від розвитку остеопорозу та оперативного методу лікування.

Таблиця 3. Біохімічні маркери кісткового обміну залежно від змін МщкТ

\begin{tabular}{|c|c|c|c|c|c|c|c|c|c|}
\hline \multirow{3}{*}{ Маркери } & \multicolumn{9}{|c|}{ "Операція } \\
\hline & \multicolumn{3}{|c|}{ ПРІСШ } & \multicolumn{3}{|c|}{ Більрот-I } & \multicolumn{3}{|c|}{ Більрот-II } \\
\hline & $\mathrm{N}$ & $\mathrm{O}-\ddot{1}$ & $\mathrm{O}-3$ & $\mathrm{~N}$ & $\mathrm{O}-\mathrm{i}$ & $\mathrm{O}-3$ & $\mathrm{~N}$ & $\mathrm{O}-\mathrm{i}$ & $\mathrm{O}-3$ \\
\hline $\mathrm{Ca}$ & $2,24 \pm 0,03$ & $2,32 \pm 0,08$ & $2,32 \pm 0,07$ & $2,08 \pm 0,06$ & $\begin{array}{l}2,33 \pm \\
0,04^{* *}\end{array}$ & $\begin{array}{c}2,30 \pm \\
0,06^{*} \\
\end{array}$ & $2,07 \pm 0,10$ & $2,19 \pm 0,03$ & $\begin{array}{c}2,29 \pm \\
0,02^{*}\end{array}$ \\
\hline $\mathrm{P}$ & $1,19 \pm 0,05$ & $1,23 \pm 0,09$ & $1,27 \pm 0,06$ & $1,01 \pm 0,05$ & $\begin{array}{l}1,31 \pm \\
0,08^{* *} \\
\end{array}$ & $\begin{array}{l}1,26 \pm \\
0,09^{*}\end{array}$ & $1,19 \pm 0,10$ & $1,27 \pm 0,04$ & $1,30 \pm 0,05$ \\
\hline $\begin{array}{l}\text { Актив- } \\
\text { ність ЛФ }\end{array}$ & $1,27 \pm 0,05$ & $1,38 \pm 0,09$ & $1,34 \pm 0,07$ & $1,02 \pm 0,04$ & $\begin{array}{c}1,45 \pm \\
0,10^{* * *}\end{array}$ & $\begin{array}{c}1,72 \pm \\
0,09^{* * *}\end{array}$ & $0,99 \pm 0,07$ & $\begin{array}{l}1,35 \pm \\
0,08^{* *}\end{array}$ & $\begin{array}{c}1,33 \pm \\
0,05^{* * *}\end{array}$ \\
\hline
\end{tabular}

Примітки:

1) * $-\mathrm{P}<0,05$;

2) ** $-\mathrm{P}<0,01$;

$3)$ *** $-\mathrm{P}<0,001$ - різниця статистично достовірна порівняно з нормальною МЩКТ у кожній окремій групі.

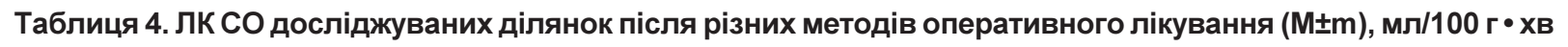

\begin{tabular}{|c|c|c|c|c|c|c|c|c|c|}
\hline \multirow{3}{*}{ Період } & \multicolumn{3}{|c|}{ ПРІСШ } & \multicolumn{3}{|c|}{ Більрот-I } & \multicolumn{3}{|c|}{ Більрот-II } \\
\hline & \multicolumn{9}{|c|}{ ділянки обстеження } \\
\hline & \multicolumn{3}{|c|}{$\begin{array}{c}\text { дванадцятипала кишка } \\
\text { (цибулина) }\end{array}$} & \multicolumn{3}{|c|}{$\begin{array}{c}\text { дванадцятипала кишка } \\
\text { (початковий відділ) }\end{array}$} & \multicolumn{3}{|c|}{$\begin{array}{c}\text { відвідна петля } \\
\text { (початковий відділ) }\end{array}$} \\
\hline \multicolumn{10}{|c|}{ Стан ЛК при різній МЩКТ у досліджуваних групах } \\
\hline \multirow{3}{*}{$\begin{array}{l}\text { До } 18 \\
\text { років }\end{array}$} & \multicolumn{3}{|c|}{$(\mathrm{n}=20)$} & \multicolumn{3}{|c|}{$(n=23)$} & \multicolumn{3}{|c|}{$(n=24)$} \\
\hline & $\begin{array}{c}\mathrm{N} \\
(\mathrm{n}=9)\end{array}$ & $\begin{array}{c}\mathrm{O}-\ddot{1} \\
(\mathrm{n}=7)\end{array}$ & $\begin{array}{c}\mathrm{O}-3 \\
(\mathrm{n}=4)\end{array}$ & $\begin{array}{c}\mathrm{N} \\
(\mathrm{n}=6)\end{array}$ & $\begin{array}{c}\mathrm{O}-\ddot{1} \\
(\mathrm{n}=10)\end{array}$ & $\begin{array}{c}\mathrm{O}-3 \\
(\mathrm{n}=7)\end{array}$ & $\begin{array}{c}\mathrm{N} \\
(\mathrm{n}=6)\end{array}$ & $\begin{array}{c}\mathrm{O}-\ddot{1} \\
(\mathrm{n}=9)\end{array}$ & $\begin{array}{c}\mathrm{O}-3 \\
(\mathrm{n}=9)\end{array}$ \\
\hline & $\begin{array}{c}55,11 \pm \\
0,43\end{array}$ & $\begin{array}{l}52,85 \pm \\
0,50^{++}\end{array}$ & $\begin{array}{l}51,02 \pm \\
0,21^{+++}\end{array}$ & $\begin{array}{c}44,38 \pm \\
1,08\end{array}$ & $\begin{array}{c}41,13 \pm \\
0,69^{+}\end{array}$ & $\begin{array}{l}36,18 \pm \\
1,69^{+++}\end{array}$ & $\begin{array}{c}39,41 \pm \\
0,71\end{array}$ & $\begin{array}{c}37,52 \pm \\
0,46^{+}\end{array}$ & $\begin{array}{l}34,45 \pm \\
0,45^{+1+}\end{array}$ \\
\hline
\end{tabular}

$\overline{\text { Примітки: }}$

1) ${ }^{+}-P<0,05$;

2) ${ }^{++}-\mathrm{P}<0,01$;

3) ${ }^{+++}-\mathrm{P}<0,001$ - вірогідна відмінність порівняно з нормальною МЩКТ. 
Після резекції за Більрот-І відмічено зниження на 7,3\% $(\mathrm{P}<0,05)$ показників ЛК у пацієнтів з остеопенією та на $18,5 \%(\mathrm{P}<0,001)$ у хворих з остеопорозом порівняно з нормальною МЩКТ.

У пацієнтів, оперованих другим методом Більрота, остеопенію супроводжує зниження ЛК на 4,8 \% а остеопороз - на 12,6 \% відносно рівноцінних даних осіб із нормальною МЩКТ.

Висновки. 1. Після проведеного хірургічного лікування виразкової хвороби шлунка у віддаленому періоді в усіх групах відмічено явища синдрому остеодистрофії.

\section{СПИСОК ЛІТЕРАТУРИ}

1. Беденюк А. Д. Мінеральна щільність кісткової тканини після різних методів хірургічної корекції гастродуоденальних виразок у віковому аспекті / А. Д. Беденюк // Вісник наукових досліджень. - 2011. - № 4. - С. 17-19.

2. Беденюк А. Д. Функціональний стан органа та локальний кровобіг слизової оболонки шлунка і дванадцятипалої кишки при ускладненій виразковій хворобі шлунка до та після хірургічного лікування / А. Д. Беденюк // Шпитальна хірургія. 2010. - № 2. - С. 25-32.

3. Беденюк А. Д. Локальний кровобіг слизової оболонки при ускладненій виразковій хворобі дванадцятипалої кишки на фоні функціональних порушень гастродуоденальної зони до та після хірургічної корекції / А. Д. Беденюк // Шпитальна хірургія. -2010 . - № 1. - С. 17-26.

4. Зайцев В. Т. Остеопороз у хворих на ускладнену виразкову хворобу шлунка та дванадцятипалої кишки / В. Т. Зайцев, В. В. Бойко, І. А. Тарабан // Проблеми остеології. - 1999. T. 2, № 1. - C. 85 .

5. Ковальчук Л. А. Возрастные изменения регионарного кровотока слизистой оболочки желудка и двенадцатиперстной кишки / Л. А. Ковальчук, Н. А. Ковальчук // Физиология человека. - 1987. - Т.13, № 1. - С. 73-76.

6. Ковальчук Л. А. Способ определения кровотока слизистой
2. На фоні зниженого локального кровобігу в початковому відділі тонкого кишечника, що супроводжує післярезекційні стани, процес абсорбції мікроелементів Са та Р в ньому знижений, що може виступати одним із аліментарних факторів в етіології розвитку вторинного післярезекційного остеопорозу.

3. Найнижчі відхилення показників швидкості локального кровобігу в початковому відділі тонкого кишечника та найменші явища остеодистрофії виявлено після органощадного методу СПВ + ПРІСШ за Л. Я. Ковальчуком, що вказує на беззаперечну пріоритетність даного методу над резекційними.

оболочки желудка / Л. А. Ковальчук // Патол. физиол. и эксперим. терап. - 1984. - № 5. - С. 78-80.

7. Проблеми остеопорозу / за ред. проф. Л. Я. Ковальчука. Тернопіль : Укрмедкнига, 2002. - 446 с.

8. Рожинська Л. Я. Системный остеопороз / Л. Я. Рожинська. - М., 2000. - 195 с.

9. Рузибаев Р. Ю. Нарушение минеральной плотности костной ткани у больных с язвенной болезнью гастродуоденальной зоны / Р. Ю. Рузибаев // Актуальні питання медичної науки та практики : зб. наук. праць. - 2006. - Вип. 70, кн. 1. C. $186-191$.

10. Рузибаев Р. Ю. Состояние костной ткани после оперативного лечения язвенной болезни желудка и двенадцатиперстной кишки по методике Бильрот-І / Р. Ю. Рузибаев // Український морфологічний альманах. - 2006. - Т. 4, № 1. - С. 62-64.

11. Рузібаєв Р. Ю. Вивчення резорбції кісткової тканини у віддаленому періоді після органозберігальних і органощадних операцій на органах гастродуоденальної зони / Р. Ю. Рузібаєв // Клінічна хірургія. - 2006. - № 9 (додаток). - С. 67-68. 12. Decreased circulating levels of vitamin D and 25hydroxyvitamin D in osteopenic elderly men / M. Tamatani, S. Morimoto, M. Nakajima [et al.] // J. Metabolism. - 1998. Vol. 47, N 2. - P. 195-199. 